\title{
High Performance CLSM Field Mixing and Pumping Test Results
}

by

R. Hayden (contact)

Westinghouse Savannah River Company

Savannah River Site

Aiken, South Carolina 29808

C. A. Langton

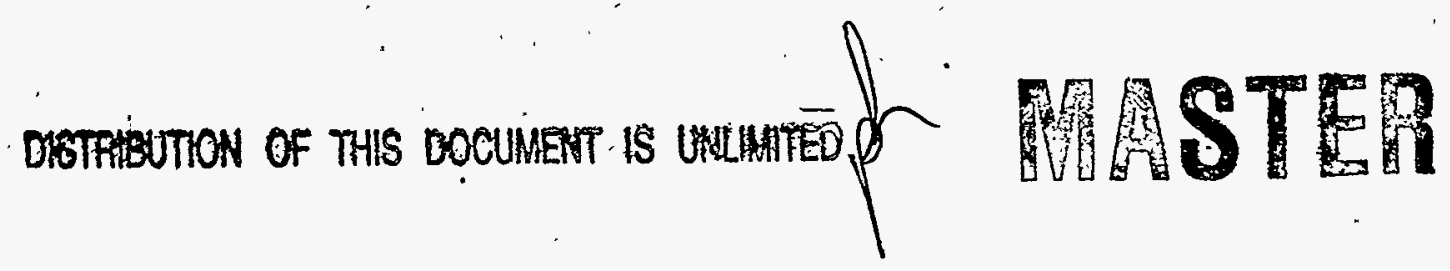

DOE Contract No. DE-AC09-96SR18500

This paper was prepared in connection with work done under the above contract number with the U.S. Department of Energy. By acceptance of this paper, the publisher and/or recipient acknowledges the U. S. Government's right to retain a nonexclusive, royalty-free license in and to any copyright covering this paper, along with the right to reproduce and to authorize others to reproduce all or part of the copyrighted paper. 


\section{DISCLAIMER}

This report was prepared as an account of work sponsored by an agency of the United States Government. Neither the United States Government nor any agency thereof, nor any of their employees, makes any warranty, express or implied, or assumes any legal liability or responsibility for the accuracy, completeness, or usefulness of any information, apparatus, product, or process disclosed, or represents that its use would not infringe privately owned rights. Reference herein to any specific commercial product, process, or service by trade name, trademark, manufacturer, or otherwise does not necessarily constitute or imply its endorsement, recommendation, or favoring by the United States Government or any agency thereof. The views and opinions of authors expressed herein do not necessarily state or reflect those of the United States Government or any agency thereof.

This report has been reproduced directly from the best available copy.

Available to DOE and DOE contractors from the Office of Scientific and Technical Information, P.O. Box 62, Oak Ridge, TN 37831; prices available from (615) 576-8401.

Available to the public from the National Technical Information Service, U.S. Department of Commerce, 5285 Port Royal Road, Springfield, VA 22161. 


\section{DISCLAIMER}

Portions of this document may be illegible electronic image products. Images are produced from the best available original document. 
WSRC-RP-97-272

May 14, 1997

Page 1 of 10

\section{WESTINGHOUSE SAVANNAH RIVER COMPANY SAVANNAH RIVER TECHNOLOGY CENTER}

\section{HIGH PERFORMANCE CLSM FIELD MIXING AND PUMPING TEST RESULTS (U)}

N. Rajendran

Bechtel Savannah River, Inc.

Aiken, SC 29808

Christine A. Langton cal

Westinghouse Savannah River Company

Savannah River Technology Center,

Aiken, SC 29808

\section{SUMMARY}

Field testing of the High Performance CLSM (Mix: WSRC TW-10) was conducted on 5-13-97 at the F-Area portable batch plant. Mix WSRC TW-10 meets all of the requirements for minimal bleed water CLSM for use in Tank 20 closure. This mix was developed in previous testing at the request of M. R. Wilson, HLWE. ${ }^{1}$

Mix WSRC TW-10 was prepared by G. L. Throop, Inc. in a portable auger plant and pumped 260 feet through a 5 inch pipeline. A Schwing BP 5000 concrete pump (165 cubic yards/hour) supplied by BSRI construction was used.

Mix TW-10 was successfully mixed and pumped into a wood form where it flowed 48 feet (entire length of the $2 \mathrm{ft}$. wide, $2.5 \mathrm{ft}$. high form). The CLSM was self-leveling in the form and had no bleed water. The CLSM in the form set with in 24 hours. Samples collected at the auger and at the pipeline discharge also had no bleed water at any time during the curing process and set with in 24 hours.

\section{BACKGROUND}

Bleed water from the original CLSM recommended for Tank 20 closure, Mix: OPAEXE-X-P-0$\mathrm{X}$, generated about $10 \%$ of the original mixing water as bleed water. This amounted to about 6 gallons per cubic yard. ${ }^{2}$ Consequently work was initiated to develop a CLSM mix which had minimal bleed water. ${ }^{1}$

The strategy for developing a modified CLSM mix was to keep the proportions of the sand, cement, and fly ash constant, reduce the amount of water while at the same time maintain the high 
flow, and identify admixtures which will prevent settling of the solid components. This will eliminate the mechanism for bleed water formation. Two types of admixtures were identified: the first is a foaming agent, Darafill (W. R. Grace) or Rheofill (Master Builders); the second is an organic polymer, Kelco-Crete (Kelco/Monsanto). In addition, water reducing admixtures which are compatible with each of these solids-suspending admixtures were identified so that the amount of the water in the mix design could also be reduced. Results of this work are presented elsewhere. ${ }^{2}$

The Kelco-Crete mix was chosen for field testing of in the portable F- Area batch plant because it appeared to be easier to mix in an auger than the foamed mix. The foamed CLSM (Mix: WSRC Q) ${ }^{2}$ was previously field tested by WSRC/SWE and their subcontractor, B \& W, as the fill material for Tank 29-E. This mix required at least 5 minutes mixing time after the admixtures were added in the concrete truck and was more challenging to pump than Kelco-Crete mix.

\section{RESULTS AND DISCUSSION}

\section{CLSM Field Production and Pumping}

Field testing was conducted in two parts. The first part was intended to optimize the admixture and water proportioning. Five mixes (all based on mix WSRC TW-10) were batched in the Throop auger plant. At least 0.5 cubic yards of each mix were prepared for the optimization work. Mix designs and measured properties are shown in Table 1. The F-Area grout bathcing and pumping facility is shown in Figures 1 and 2.

An optimized mix design was chosen for the pumping evaluation. This mix is shown in Table 2. Four cubic yards of the optimized mix were prepared and pumped 260 feet. Samples were collected at the auger and at the end of the pipeline. See Figure 3. Bleed water, flows, air contents, and unit weights were measured for material collected at these two locations. Samples were also collected for compressive strength measurements. Results are presented in Table 3.

All samples had no bleed water and flows of greater than 9 inches as measured by the ACI 229 recommended practice. The material was collected in a form $2 \times 2.5 \times 48$ feet. The CLSM flowed very well in the form. It was self leveling, cohesive, showed no segregation, and had no bleed water. See Figure 4.

\section{Admixture Systems}

Previous testing to identify compatible admixtures for the Kelco-Crete system indicated that Advaflow or Advacast (W. R. Grace) could be mixed directly with the Kelco-Crete. Consequently the admixture calibration, metering and addition can be accomplished with only one preblended liquid. Limited testing with other high range water reducers ${ }^{1}$ indicated that the Advaflow and Advacast products were the easiest to mix with the Kelco-Crete. In the optimization testing (mixes: WSRC TW-10, 1-5), two different blends of Advacast and Kelco-Crete were evaluated. The amount of Kelco-Crete was the same in both blends. The amount of the Advaflow was varied The blends were prepared on a cubic yard basis as follows:

a) 90 liquid ounces of Advaflow plus 275 grams of Kelco-Crete per cubic yard of CLSM and

b) 75 liquid ounces of Advaflow plus 275 grams of Kelco-Crete per cubic yard. .

The best results were obtained with the blend containing the higher amount of Advaflow. 
One precaution which must be emphasized is that the Kelco-Crete should not be mixed with water prior to adding it to the auger. The Kelco-Crete hydrates rapidly in water to form a gel which is difficult to meter and mix in the auger batching plant.

\section{Moisture Condensation}

After curing for 20 hours the samples collected for bleed water determinations showed some condensation. This water collects on the surface and is the result of evaporation and subsequent condensation in the sealed sample container. This moisture is not bleed water which is generated from solid-liquid phase separation due to solids settling. The physical phenomenon causing this situation is referred to as "sweating" and is aggravated by temperature fluctuations in closed containers such as the sample containers.

\section{CONCLUSIONS}

An improved low bleed water CLSM mix was field tested on May 13, 1997 at the Throop portable auger batching plant. Production and pumping tests were very successful. The four cubic yards of material pumped into a ply wood form where it flowed 48 feet (the entire length of the form). The CLSM slurry was very uniform, self leveling, cohesive, showed no segregation, and had no bleed water.

Properties of the High Performance CLSM were the same for material collected at the auger and at the end of the pipeline except for the air content which was $5.5 \%$ at the auger and $3.2 \%$ at the end of the pipeline. This is exactly what was expected and indicates that this CLSM is easy to mix and pump in the Throop/BSRI equipment.

\section{RECOMMENDATIONS.}

CLSM Mix TW-10 is recommended for Tank Closure based on the field batching and pumping tests. A DCF has been issued and the High Performance CLSM mix has been identified as OPB EXE-X-P-0-S. See Table 2

Pre blend the high range water reducer and the organic polymer gelling admixture to simplify metering and mixing in the CLSM.

Monitor CLSM and the 2000 psi grout in Tank 20 for sweating. If moisture accumulation on the surfaces of the fill is observed, provide ventilation or another means of drying (dry cement addition) to minimize the chance of spills at access ports. Also provide spill containment for all access ports as a routine precaution in case moisture does accumulate in areas where it can not be removed.

Test the HRWR-polymer system (Advaflow-Kelco-Crete) developed for reducing bleed water in CLSM or system using an alternative HRWR and Kelco-Crete for reducing the bleed water in the 2000 psi grout mix design. 
WSRC-RP-97-272

May 14, 1997

Page 4 of 10

\section{REFERENCES}

1. WSRC-RP-97-271, C. Langton and N. Rajendran, CLSM Bleed Water Reduction Test Results (U), 4-21-97.

2. WSRC-RP-96-554, N. Rajendran, C. Langton and T. M. Nixon, Bleed Water Testing Program for Controlled Low Strength Material (CLSM) (U), 10/22/96.

\section{ACKNOWLEDGEMENTS}

K. H. Hudson, W. L. Mhyre, M. L. Troutman, and TW. Mathias from the on-site Raytheon Testing Laboratory calibrated the G. L. Throop equipment along with the Throop personnel. They also performed sample collection and evaluation to support this CLSM field testing. BSRI Construction provided support in operating the pump and preparing the 48 foot long form for the final testing. G. L. Throop personnel mixed the CLSM. 
Table 1. High Performance CLSM Optimization Experiments for Material Produced in the Throop Portable Auger Batching Plant.

\begin{tabular}{|c|c|c|c|c|c|c|c|c|c|c|}
\hline $\begin{array}{l}\text { Cement } \\
\text { Type I } \\
\text { (lbs/cuyd) }\end{array}$ & $\begin{array}{l}\text { Fly Ash } \\
\text { Class F } \\
\text { (lbs/cuyd) }\end{array}$ & $\begin{array}{l}\text { Sand } \\
\text { C-33 } \\
\text { (lbs/cuyd) }\end{array}$ & $\begin{array}{l}\text { Water } \\
\text { (gal/cuyd) }\end{array}$ & $\begin{array}{l}\text { Advaflow } \\
\text { (oz/cuyd) }\end{array}$ & $\begin{array}{l}\text { Kelco-Crete } \\
\text { (gms/cuyd) }\end{array}$ & $\begin{array}{l}\text { Blended } \\
\text { Admixture } \\
\text { Ratio* }\end{array}$ & $\begin{array}{l}\text { Blended } \\
\text { Admixture } \\
\text { (oz/cuyd) }\end{array}$ & $\begin{array}{l}\text { Flow } \\
A C I 229 \\
\text { (inches) }\end{array}$ & $\begin{array}{l}\text { Bleed } \\
\text { Water } \\
\text { (vol. }\end{array}$ & $\begin{array}{l}\text { SetTime } \\
A S T M C- \\
403 \text { (hr.) }\end{array}$ \\
\hline
\end{tabular}
Test No. (lbs/cuyd) (lbs/cuyd) (lbs/cuyd) (gal/cuyd) $\quad$ (oz/cuyd) $\quad \begin{array}{lllll}\text { (gms/cuyd) Ratio* } & \text { (oz/cuyd) (inches) (vol } & \text { \%) }\end{array}$

\begin{tabular}{|c|c|c|c|c|c|c|c|c|c|c|c|}
\hline 1 & 150 & 500 & 2484 & 62.7 & 90 & 275 & $90 / 275$ & 96 & 10.75 & 0 & $\sim 24$ \\
\hline 2 & 150 & 500 & 2484 & 60.1 & 90 & 275 & $90 / 275$ & 96 & 10.5 & 0 & $\sim 18$ \\
\hline 3 & 150 & 500 & 2484 & 62.7 & 72.7 & 222 & $90 / 275$ & 77.6 & 10.5 & $<1$ & $\sim 24$ \\
\hline 4 & 150 & 500 & 2484 & 62.7 & 75 & 275 & $75 / 275$ & 83.2 & 8.75 & $<1$ & $\sim 24$ \\
\hline 5 & 150 & 500 & 2484 & 62.7 & 80.8 & 296 & $75 / 275$ & 89.6 & 10.25 & 0 & $\sim 24$ \\
\hline
\end{tabular}

*Two different admixture blends were prepared. The first was blend was equivalent to 90 liquid ounces of Advaflow per cubic yard of CLSM plus 275 grams of Kelco-Crete per cubic yard. The second blend was equivalent to 75 liquid ounces of Advaflow per cubic yard plus 275 grams of Kelco-Crete per cubic yard of CLSM. 
WSRC-RP-97-272

May 14, 1997

Page 6 of 10

Table 2. Optimized High Performance CLSM Mix Design, WSRC TW-10, Used in the Field Mixing and Pumping Test.

\begin{tabular}{|c|c|c|c|c|}
\hline $\begin{array}{c}\text { Cement (Type I) } \\
\text { (lbs/cuyd) }\end{array}$ & $\begin{array}{l}\text { Fly Ash (Class F) } \\
\text { (lbs/cuyd) }\end{array}$ & $\begin{array}{c}\text { Sand (C-33) } \\
\text { (lbs/cuyd) }\end{array}$ & $\begin{array}{c}\text { Water } \\
\text { (gal/cuyd) }\end{array}$ & $\begin{array}{l}\text { Pre Blended } \\
\text { HRWR/Gum } \\
\text { (90/275 mix)* } \\
\text { (oz/cuyd) }\end{array}$ \\
\hline 150 & 500 & $\begin{array}{c}2300 \\
2484^{*}\end{array}$ & $63(\max )$ & 96 (max.) \\
\hline
\end{tabular}

*The actual weight of the sand used was 2484 pounds. This sand contained $7.4 \mathrm{wt}$. \% moisture which was added from the total sand weight and subtracted into the mix water volume.

Table 3. Properties of WSRC TW-10 Prepared in the Field Test 5-14-97 at the F-Area Portable Auger Plant.

\begin{tabular}{|c|c|c|c|c|c|}
\hline $\begin{array}{l}\text { Sample } \\
\text { Collection } \\
\text { Point } \\
\end{array}$ & $\begin{array}{l}\text { Flow } \\
A C I 229 \\
\text { (inches) }\end{array}$ & $\begin{array}{l}\text { Bleed Water } \\
\text { (vol. } \% \text { of mix } \\
\text { water)* }\end{array}$ & $\begin{array}{l}\text { Air Content } \\
A S T M C-x x x x \\
\text { (vol. \%) }\end{array}$ & $\begin{array}{l}\text { Fresh Unit Weight } \\
A S T M C-138 \\
\text { (lbs/cuft) }\end{array}$ & $\begin{array}{l}\text { Set Time } \\
A S T M C-403 \\
\text { (hours) }\end{array}$ \\
\hline $\begin{array}{l}\text { End of Auger } \\
\text { Mixer }\end{array}$ & 9.5 & $\begin{array}{c}0 \text { after } 2,18, \\
24 \mathrm{hr} .\end{array}$ & 5.5 & 123 & 18 \\
\hline $\begin{array}{l}\text { End of } 260 \mathrm{ft} \text {. } \\
\text { Pipeline }\end{array}$ & 9.25 & $\begin{array}{c}0 \text { after } 2,18 \text {, } \\
24 \mathrm{hr} .\end{array}$ & 3.0 & 125 & 24 \\
\hline
\end{tabular}

- Sweating of the CLSM samples was observed. This resulted in a few droplets of water on the surfaces of all of the samples after they set (after curing for more than 24 hours). This moisture is due to evaporation and subsequent condensation of pore water in the solidified CLSM and was caused by temperature fluctuations of the samples stored outdoors and in the Throop office. This should not be confused with bleed water which is formed as the result of solids settling out of a liquid suspension prior to setting. 


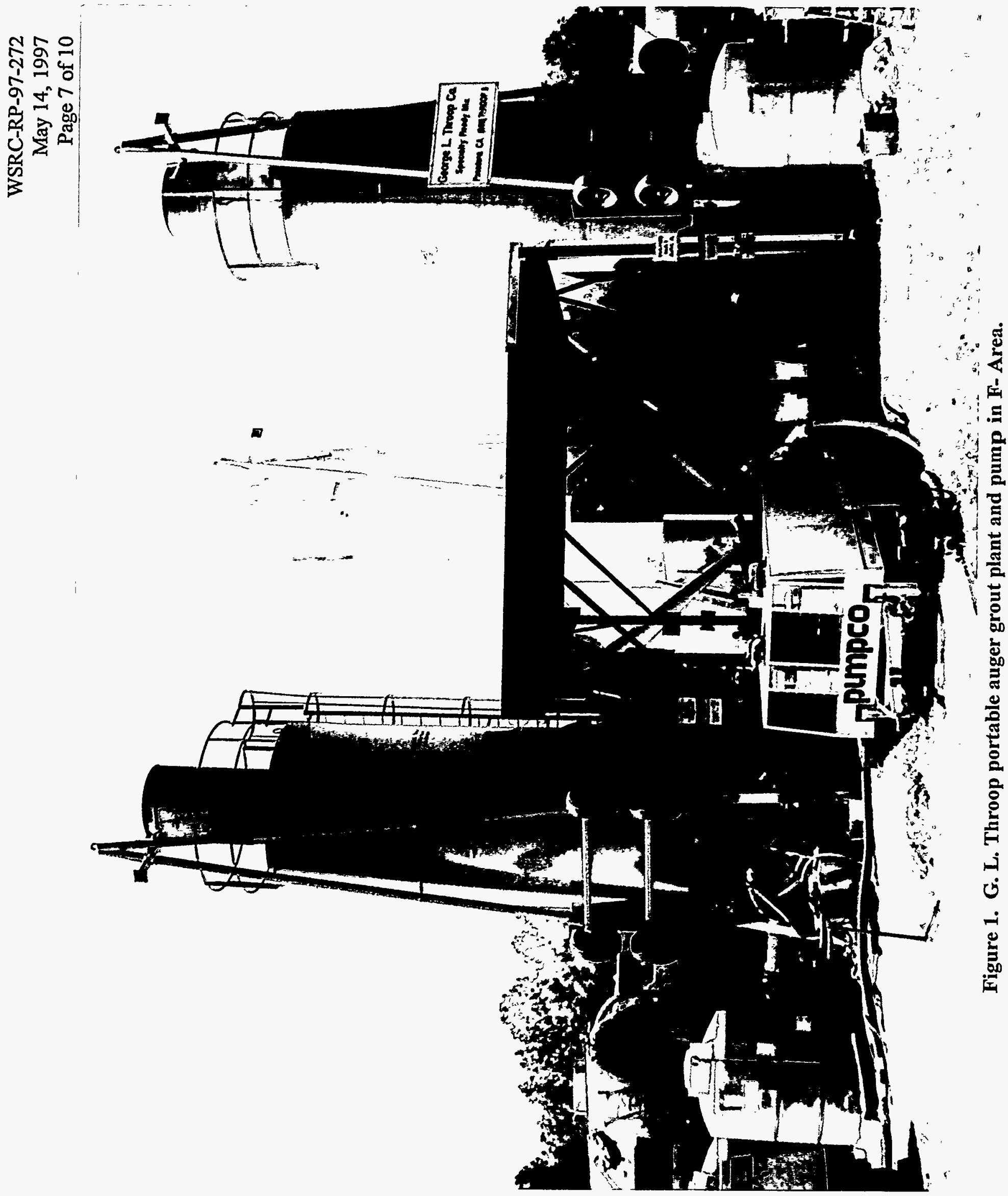




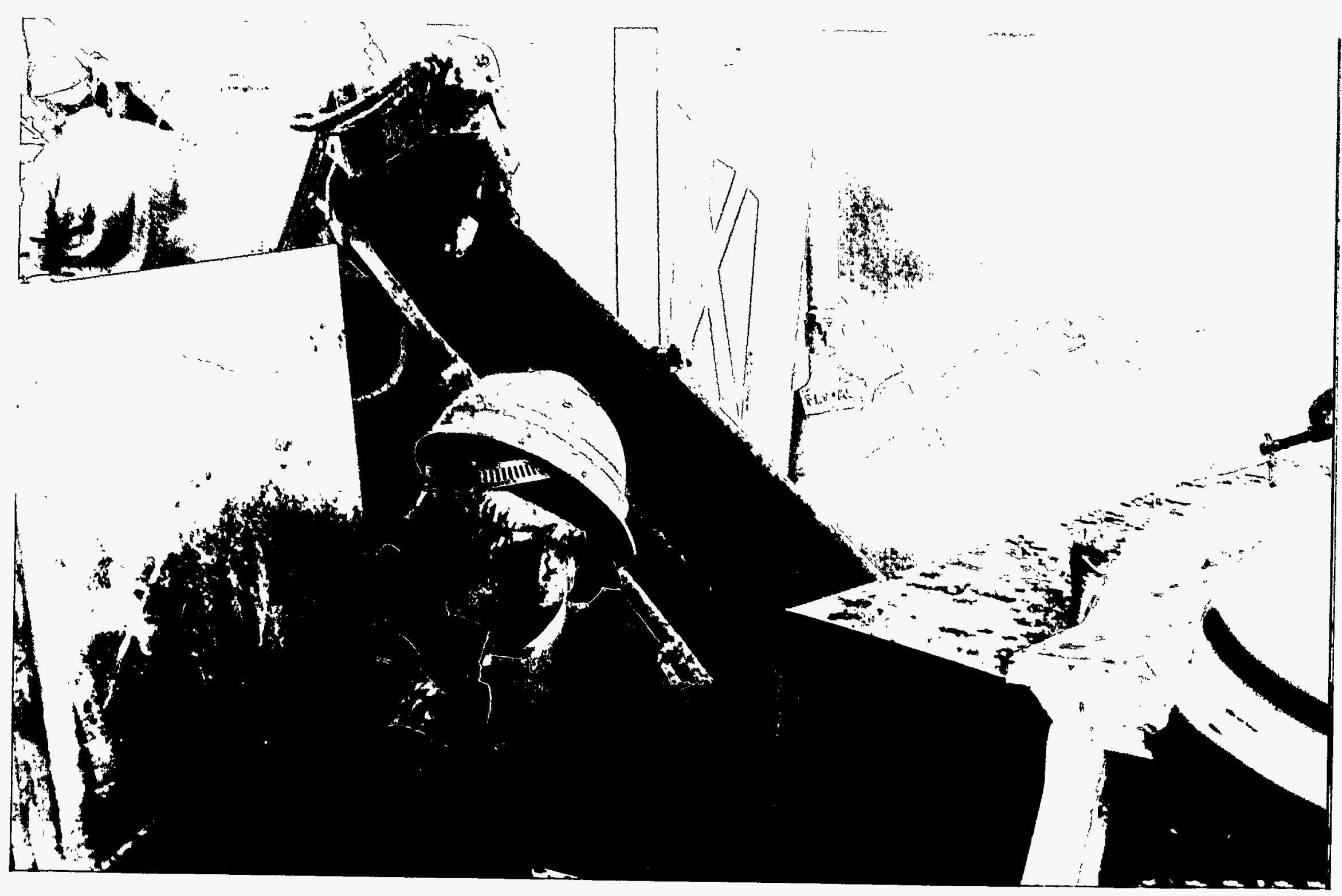

Figure 2. High performance Controlled Low Strength Material discharged from the auger mixer into the grout pump. 


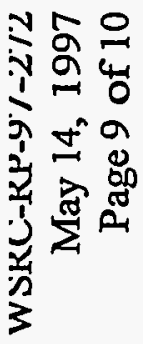

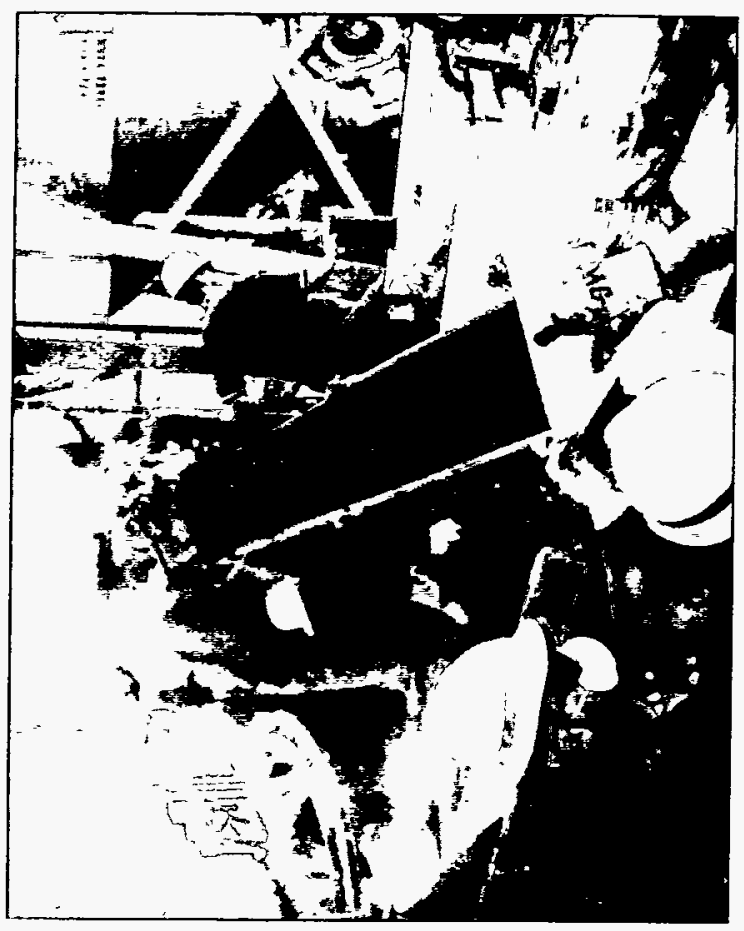

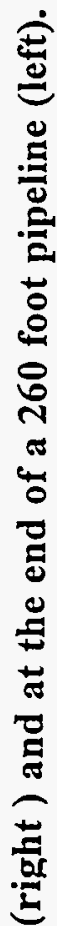

范

นู

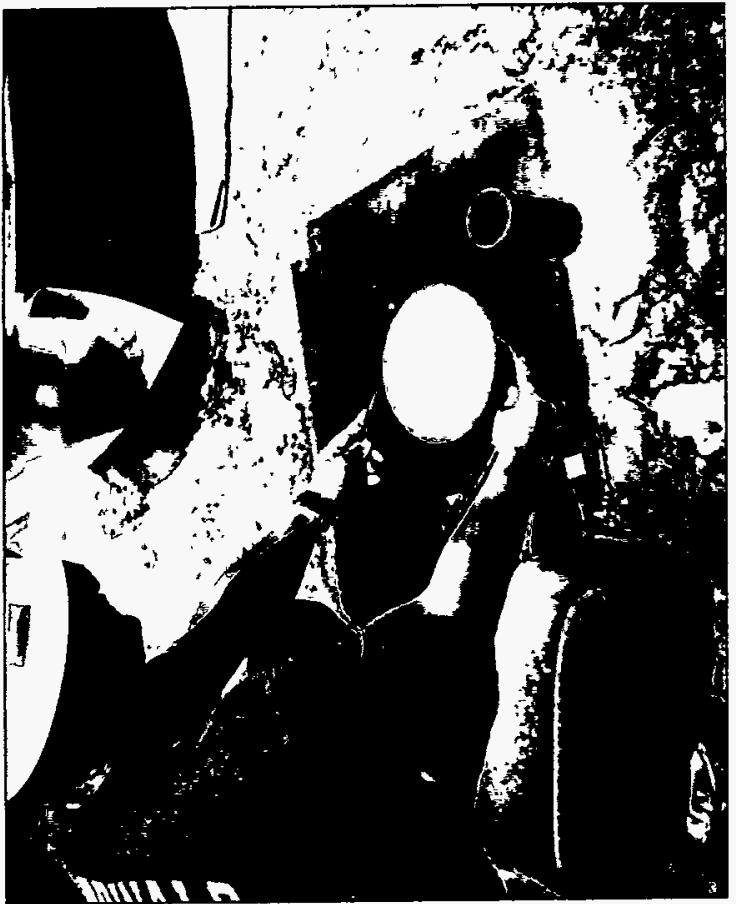




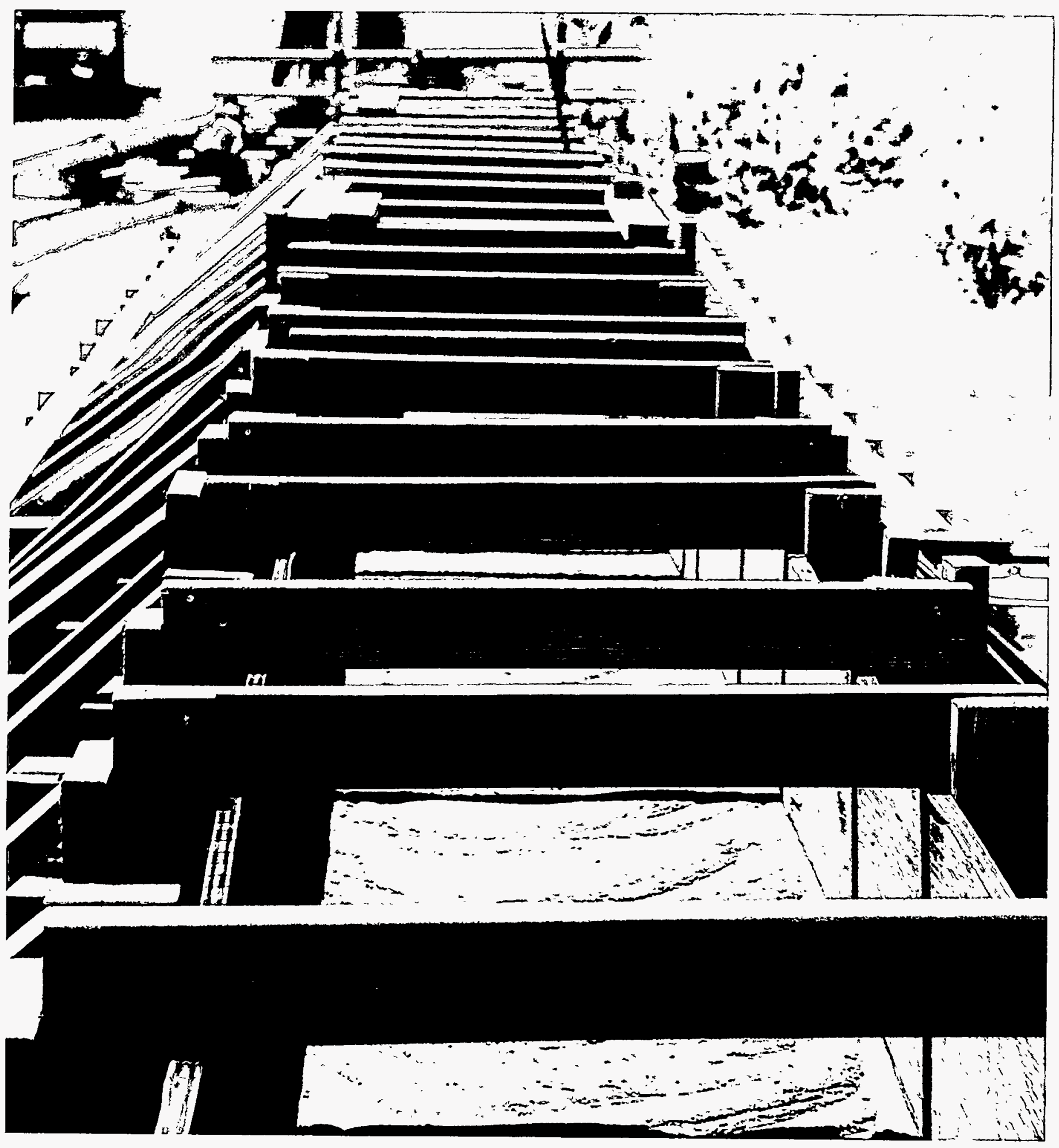

Figure 4. High Performance CLSM Poured Into $2 \times 2.5 \times 48$ foot form, 5/13/97 